\title{
Foreword by Senior Minister and Coordinating Minister for National Security, Singapore, Teo Chee Hean
}

I have known Pak Sarwono Kusumaatmadja for more than twenty years, going back to the time when he was Indonesia's State Minister for the Environment when I served as Singapore's Minister for the Environment from 1995 to 1997. I readily agreed when I was invited to contribute a foreword for the English translation of his memoir.

Pak Sarwono has had a long and distinguished career in politics and government,

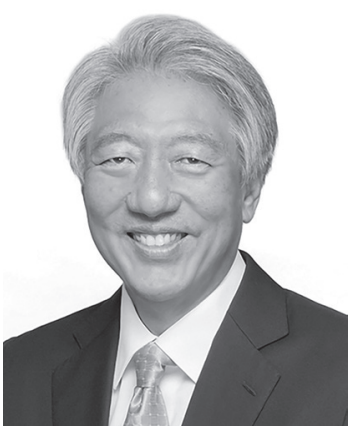
spanning the New Order and Reformasi eras.

He cut his teeth as a member of the House of Representatives (DPR) from 1971 to 1988, during which he served as Secretary of the Golkar faction from 1973 to 1987 . He was an astute politician who became the first civilian to be appointed Secretary General of Golkar in 1983. His appointment, when he was just forty years old, injected youth, energy and fresh ideas into the party. Having established a strong track record, Pak Sarwono was appointed to then-President Soeharto's Cabinet in 1988.

Pak Sarwono is a social activist at heart. His spirit of service and dedication to the Indonesian people became his hallmark throughout his years in government. As State Minister for Administrative Reform from 1988 to 1993, he improved the public service and professionalized 
the bureaucracy, including the education sector. As State Minister for the Environment from 1993 to 1998, Pak Sarwono recognized that environmental sustainability was key to long-term national development, and he introduced policies to incentivize Indonesian companies and people to preserve and protect the environment. He depended not only on his formal authority as the Minister, but also astutely drew on his instincts as a social activist and his links to NGOs and the media to achieve his aims. He was among the first to recognize the link between corporate practices and the environment. As Minister for the Environment, he proactively worked with the international community to manage environmental challenges such as transboundary haze. Pak Sarwono was subsequently appointed Indonesia's first Minister of Marine Affairs and Fisheries from 1999 to 2001, during which he laid the groundwork for the development and sustainable management of Indonesia's marine and fisheries resources.

Pak Sarwono made several working visits to Singapore, in both his capacities as Golkar Secretary General and Cabinet Minister. He engaged our leaders with candour about Indonesia and its views about Singapore and the world, and he worked hard to strengthen Singapore-Indonesia cooperation for mutual benefit.

Pak Sarwono's memoir traces his formative experiences as a young man coming of age in a newly independent Indonesia. No doubt these experiences shaped his orientation as an activist and a patriot, and his journey in becoming an important actor in Indonesia's remarkable development over the decades. His memoir provides insights on key events in Indonesia's post-independence history and the crucible of Indonesian politics. For friends and observers of Indonesia, there are many valuable lessons to be learnt from this vivid, engaging and important memoir.

Teo Chee Hean 